APLL Advances in Peer-Led Learning

$\begin{array}{lll}\text { Number } 1 & \text { Fall } 2021 \quad \text { Article } 14\end{array}$

Fear Became Fascination

Mikayla Rodriguez

Recommended Citation

Rodriguez, M. (2021). Fear Became Fascination. Advances in Peer-Led Learning, 1, 162. Online at https://doi.org/10.54935/apll2021-01-14-162 


\title{
Fear Became Fascination
}

\author{
Mikayla Rodriguez
}

Sorrow and worry occupied the air.

A novel virus sent the world in despair.

Masked smiles and conversations.

Social distance felt like isolation.

I had an opportunity to learn, rather than be overturn'd.

In search for an explanation,

Fear became fascination.

I realized that I was capable, despite the means available.

I was firm to find a purpose,

And so, I chose an act of service.

Dedicated to lessons of science, hopeful beings formed an alliance.

Sharing one goal - to learn. 